\title{
The public health care system and primary care services in Saudi Arabia: a system in transition
}

\author{
Mushabab Al Asmri, ${ }^{1}$ Mohammed J. Almalki, ${ }^{2}$ Gerry Fitzgerald ${ }^{3}$ and Michele Clark ${ }^{4}$
}

${ }^{1}$ Asser Health Affairs, Ministry of Health, Riyadh, Saudi Arabia. ${ }^{2}$ Faculty of Public Health and Tropical Medicine, Jazan University, Jazan, Saudi Arabia. ${ }^{3}$ School of Public Health, Faculty of Health, Queensland University of Technology, Brisbane, Australia. ${ }^{4}$ School of Clinical Sciences, Queensland University of Technology, Brisbane, Australia. (Correspondence to: Mohammed Almalki: mjalmalki@jazanu.edu.sa).

\begin{abstract}
Background: Saudi Arabia has invested heavily in its health care system by establishing health care infrastructures to improve health of the nation. However, it remains to be seen whether it is efficient and effective in providing health care services needed. Primary health care, which is the basis of universal health coverage, needs to be assessed on its performance, challenges and future opportunities to serve the Saudi Arabian population.

Aims: This review aimed to identify challenges within the Saudi Arabian health care system with a focus on primary health care services, and to analyse the interrelated factors in order to suggest remedial reforms to further strengthen and improve the health care system.

Methods: A narrative review of previous studies and governmental reports was undertaken to extract, analyse, synthesize and report the findings.

Results: The review found a number of key areas for improvement in the primary health care system. These areas include: the scope, structure, infrastructure, financing, increased demand, increased costs and workforce capacity. Other critical challenges include inequitable access to health services, quality and safety of services, the growing burden of chronic diseases, lack of an effective information system, management and leadership issues, and gaps in the referral system.
\end{abstract}

Conclusion: The Saudi Arabian health care system needs comprehensive reform with a focus on primary health care.

Keywords: delivery of health care, health services, primary health care, Saudi Arabia

Citation: Al Asmri M; Almalki MJ; Fitzgerald G; Clark M. The public health care system and primary care services in Saudi Arabia: a system in transition. East Mediterr Health J. 2020;26(4):468-476. https://doi.org/10.26719/emhj.19.049

Received: 04/10/16; accepted: 07/08/18

Copyright (C) World Health Organization (WHO) 2020. Open Access. Some rights reserved. This work is available under the CC BY-NC-SA 3.0 IGO license (https://creativecommons.org/licenses/by-nc-sa/3.o/igo).

\section{Introduction}

In spite of substantial improvements in the Saudi Arabian health services sector in the past few decades, the country is facing a number of challenges in its primary health care system. These challenges include increased demand because of rapid population growth, high costs of health care services, inequitable access, concerns about the quality and safety of care, a growing burden of chronic diseases, a less than effective electronic health system (eHealth), poor cooperation and coordination between other sectors of care, and a highly centralized structure (1-5). The government has developed and implemented a number of initiatives which include the Strategic Plan of the Ministry of Health 2010-2020 to effectively tackle these challenges (6). These initiatives resulted in the replacement of seven ministers of health in almost two years, which indicates the serious administrative and practical difficulties in tackling these challenges in the health care system.

Most review papers in Saudi Arabia have focused on hospital-based medical services with limited consideration of primary health care services, which are the first point of access to health care in the Saudi Arabian health care system. The primary health care sector provides essential health care services to Saudi Arabians and to expatriates working in the public sector (7). No reform of the Saudi Arabian health care system can be complete without first considering the primary health care services at the heart of the health care system.

This narrative review aimed to explore the challenges facing the Saudi Arabian health care system with a focus on primary health care services. It further discusses and analyses the barriers to and drivers of health sector reforms, including the effect of demographic and economic factors on the health care system. The review also recommends mechanisms for effective reform of primary health care services as the nucleus of overall health care system.

\section{Methods}

Data relating to the Saudi Arabian health care system were extracted from published literature in the following databases: PubMed, MEDLINE, CINAHL, Saudi Medical Journal, Eastern Mediterranean Health Journal, and the portal of the Ministry of Health in Saudi Arabia. A further search using Google Scholar search engine was carried out to identify other relevant papers and documents, government reports and information published in Arabic. All the studies and documents were analysed for their content and the relevant information was synthesized and reported. 


\section{Results and discussion}

Saudi Arabia is a country with a culture and traditions rooted in Islamic teachings and Arab customs (8). Saudi Arabia is a kingdom with an integrated system of government based on the principles of justice, consultation and equality in accordance with Islamic law (9). Therefore, to some extent, the principles of Islam and Saudi Arabian traditions influence the culture of organizations within the country. The centralized tradition of Saudi Arabian society is also embodied in the health care service $(10,11)$. In other words, the structure and functioning of the health care organizations, including primary health care, are strongly influenced by the society's norms and traditions.

\section{Demographic impacts}

The population of Saudi Arabia was estimated to be about 30 million in 2014 with expatriates comprising about 31\% of the total population (7). The population growth rate was $2.81 \%$ from 2010 to 2015 (12), which has driven demand for more health care. Although increased financial resources have been allocated to the health sector, the population is growing faster than the health services made available. This indicates an urgent need to tackle this important challenge (Table 1) (13-17).

\section{Economic impacts}

Saudi Arabia is a leading oil exporter; oil exports account for almost $69 \%$ of the country's exports (18). According to the World Bank, Saudi Arabia is classified as a high-income country (19). The strong oil-based economy has facilitated the development of local public and private organizations, creating new jobs and raising the socioeconomic status of Saudi Arabian citizens (20). The Saudi Arabian government provides free public services including health care to its population (21). However, the global instability of oil prices in the past few years has affected public and private services and encouraged the Saudi Arabian Government to explore alternate sources for revenue. The 2030 National Vision for Saudi Arabia seeks long-term sustainability of living standards by diversifying the country's income sources in the future, rather than relying only on oil revenue (22).

\section{Saudi health care system}

The Ministry of Health is responsible for public health care services (23). A number of semi-independent bodies, the private sector and nongovernmental organizations also provide health care services. The Ministry of Health provides $60 \%$ of health services while the private sector provides $23 \%$ and other government health sectors provide $17 \%(17)$.

\section{Levels of care in the Saudi health care system}

There are three levels of health care services in Saudi Arabia: primary, secondary and tertiary. However, in reality, there are four levels of care as shown in Figure 1. The primary health care services are the focus of the following discussion.

\section{Primary health care in Saudi Arabia}

Primary health care is the first level of health care service (6). It is provided by the Ministry of Health through a network of primary health care centres. However, primary health care services face many challenges in terms of the patterns of disease, workforce, information systems, financial support and accessibility.

\section{Historical issues of primary health care}

In accordance with the Alma-Ata declaration, Saudi Arabia has committed to develop its primary health care services (24). The Ministry of Health integrated both preventive and basic curative health care services in 1984. These services targeted individuals, families and the community, and provided a range of health care services including maternal and child health, immunization for communicable diseases, follow-up for patients with chronic diseases, dental care services, health education and essential drugs $(24,25)$.

\begin{tabular}{|c|c|c|c|c|c|c|c|}
\hline \multirow[t]{2}{*}{ Year } & \multicolumn{5}{|c|}{ Health resources indicators } & \multirow{2}{*}{$\begin{array}{l}\text { Population } \\
\text { growth rate } \\
\text { (\%) }\end{array}$} & \multirow{2}{*}{$\begin{array}{l}\text { Estimated } \\
\text { population }\end{array}$} \\
\hline & $\begin{array}{c}\text { Hospital beds }{ }^{\text {a }} \\
\text { (government and } \\
\text { private) }\end{array}$ & $\begin{array}{c}\text { Primary health care } \\
\text { centres }^{\mathrm{a}}\end{array}$ & $\begin{array}{l}\text { Physicians and } \\
\text { dentists }^{\text {a }}\end{array}$ & $\begin{array}{l}\text { Nurses and } \\
\text { midwives }^{a}\end{array}$ & $\begin{array}{l}\text { Allied health } \\
\text { professionals }^{\mathrm{a}}\end{array}$ & & \\
\hline 2006 & 23.0 & 0.81 & 20.4 & 35.4 & 19.0 & 2.32 & 23678849 \\
\hline 2007 & 22.1 & 0.79 & 21.0 & 38.7 & 20.0 & 2.28 & 24242578 \\
\hline 2008 & 21.7 & 0.80 & 21.5 & 40.8 & 20.8 & 2.23 & 24807273 \\
\hline 2009 & 22.0 & 0.80 & 21.8 & 43.3 & 23.5 & 2.20 & 25373512 \\
\hline 2010 & 21.4 & 0.77 & 24.3 & 48.0 & 25.0 & 3.19 & 27136977 \\
\hline 2011 & 20.7 & 0.74 & 24.4 & 47.4 & 27.8 & 3.19 & 28376355 \\
\hline 2012 & 20.9 & 0.77 & 27.8 & 47.8 & 26.3 & 3.19 & 29195895 \\
\hline 2013 & 21.6 & 0.75 & 26.8 & 51.5 & 30.6 & 2.70 & 29994272 \\
\hline 2014 & 22.1 & 0.74 & 26.5 & 53.7 & 30.9 & 2.55 & 30770375 \\
\hline
\end{tabular}

${ }^{a}$ Per 10 ooo population.

The red arrows show the decreasing number of in beds and primary health care centres per 10000 population; the green arrow shows the increasing total population. Source: Health statistics annual books (13-17). 


\begin{tabular}{|c|c|}
\hline $\begin{array}{l}\text { FOURTH LEVEL } \\
\text { Referral hospitals } \\
\text { (Medical cities) }\end{array}$ & $\begin{array}{l}\text { Provide specialized diagnostic, curative, surgical and rehabilitative } \\
\text { services. In addition, these facilities work as research and teaching } \\
\text { centres. They receive referred patients from the third level of care. } \\
\text { However, admission to these facilities is very limited. }\end{array}$ \\
\hline $\begin{array}{l}\text { THIRD LEVEL } \\
\text { Central hospitals }\end{array}$ & $\begin{array}{l}\text { Provide advanced diagnostic, curative, surgical and rehabilitative } \\
\text { services. Patients who need specialized health services are trans- } \\
\text { ferred to the fourth level of care. }\end{array}$ \\
\hline $\begin{array}{l}\text { SECOND LEVEL } \\
\text { General hospitals } \\
\text { and peripheral } \\
\text { (community) } \\
\text { hospitals }\end{array}$ & $\begin{array}{l}\text { Provide diagnostic and curative services through emergency de- } \\
\text { partments, outpatient clinics, hospitalization and minor surgeries. } \\
\text { Patients who need a higher level of health services are transferred to } \\
\text { the third level of care. }\end{array}$ \\
\hline $\mathrm{C}$ & \\
\hline $\begin{array}{l}\text { FIRST LEVEL } \\
\text { Primary health care }\end{array}$ & $\begin{array}{l}\text { Provide the basic curative, preventive and promotive services. Pa- } \\
\text { tients who need a higher level of health services are transferred to } \\
\text { the second level of care. }\end{array}$ \\
\hline
\end{tabular}

Primary health care services have improved considerably in the past four decades which has resulted in better health outcomes, for example a lower infant mortality rate, lower incidence of communicable diseases and an increase in average life expectancy (6). According to the Ministry of Health, there were 2281 public primary health care centres across the country in 2014 (17).

Saudi Arabia has seen changes in disease patterns with a shift away from communicable diseases to chronic diseases which are becoming more prevalent (6). These diseases place an increased burden on existing health care services $(1,6,26-28)$. This change in disease pattern suggests that primary health care services, including patient follow-up strategies and preventive and health education activities, are insufficient. Recent data from the Saudi Health Information Survey show high rates of diabetes $-14.8 \%$ for males and $11.7 \%$ for females. Diabetes prevalence was $19.9 \%$, almost double in those who were obese in comparison with non-obese (28). There is a real need to develop primary health care services directed to patients with chronic diseases and people who are most at high risk of these diseases.

\section{Health system financing and expenditure}

Saudi Arabian citizens have free access to all levels of public health care services available in the country, which is funded by the central government. The Ministry of Health expenditure per capita has increased substantially by $0.41 \%$ (17), which is equivalent to US\$ 299 per capita (13-17,29-32). However, Saudi Arabia still spends less per capita on health than a number of industrialized nations (Figure 2) (33).

Ministry of Health planners and leaders focus primarily on hospitals rather than primary health care centres. According to one report, more than $90 \%$ of the Ministry of Health budget allocated for infrastructure and development projects was spent on hospitals (21). Low expenditure on primary health care centres has resulted in $80 \%$ of primary health care buildings being rented; as such they are not specifically designed to provide health care services and they lack the necessary structural features to provide primary care $(21,34)$.

According to government regulations, the budget for the Ministry of Health is released after approval of the Ministry of Finance. This practice may influence the performance and efficiency of the Ministry of Health and delay its work in all sectors including the primary health care services.

A comparison of the primary health care systems in Saudi Arabia and Cuba shows that health leaders and the government in Cuba saw primary health care as the cornerstone of successful health care together with a focus on the social determinants of health. Cuba's approach has contributed to making its primary health care among the best in the world (35). The Saudi Arabian Ministry of Health should shift the focus of the health system from hospital-based health care services to the primary preventive and promotive health care services to deal effectively and efficiently with the increasing burden of chronic diseases.

\section{Workforce of primary health care}

Shortage of health care professionals is a global concern (36). The Saudi Arabian health care system is not immune to this challenge, and most health care professionals in Saudi Arabia are expatriates (1). In 2014, the primary health care workforce included 9304 physicians and dentists (3 per 10000 inhabitants), 18136 nurses (5.9 per 
Figure 2 Health expenditure per capita in various countries, 2016 (33)

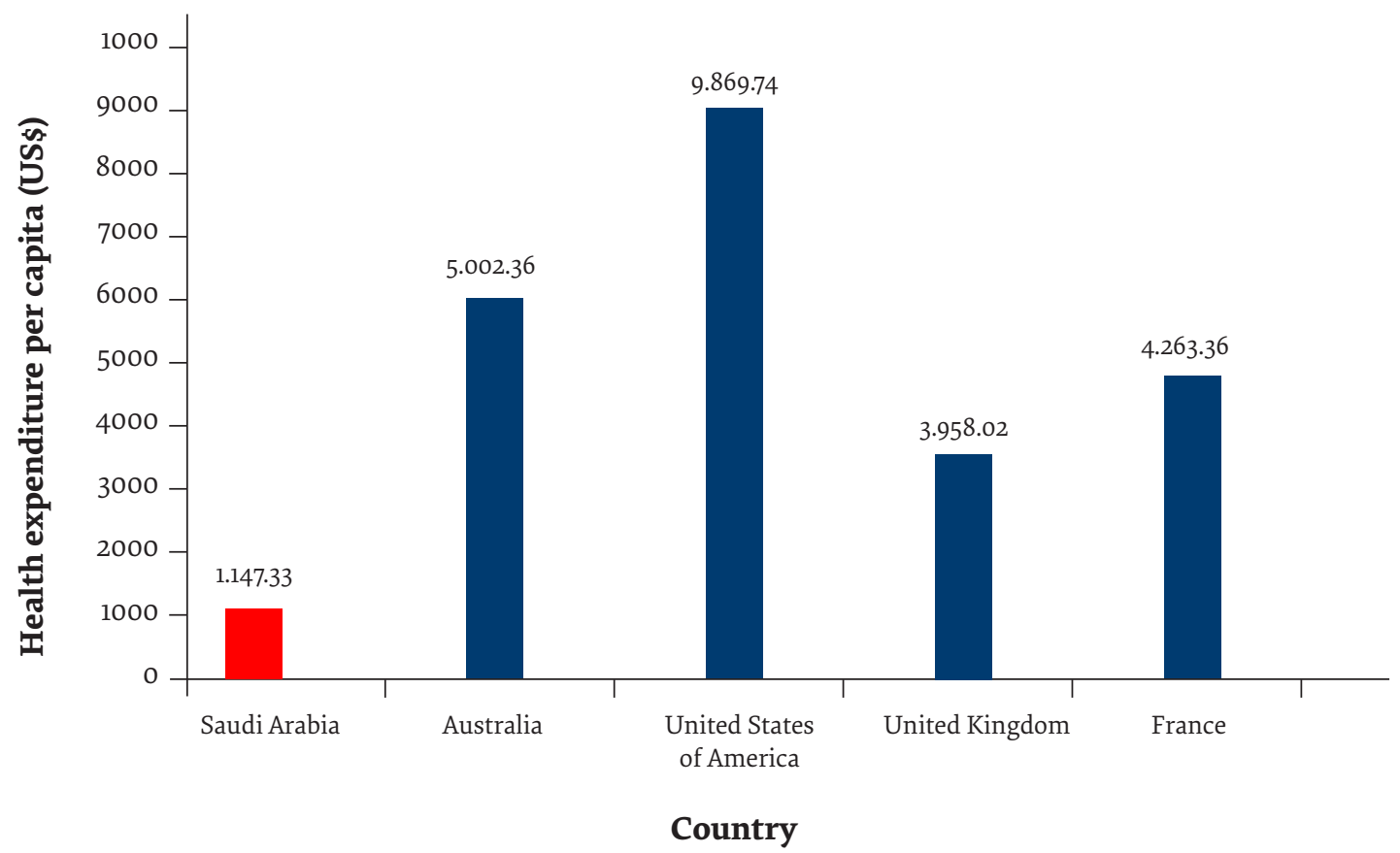

10000 inhabitants), and 9690 allied health workers (17). The health care workforce for primary health care services has increased with nurses outnumbering physicians and allied health workers between 2010 and 2014 (Figure 3) (13-17).

Many health care professionals, particularly nurses, move to management or other non-nursing departments within their organizations (37). This trend is also seen among physicians. A ministerial committee review found that the number of primary health care physicians was $40 \%$ less than the required (21). In 2013 the total number of physicians (excluding dentists) per 10000 population in Saudi Arabia was 2.3 (16). The scarcity of physicians in Saudi Arabia is high compared with other countries (Figure 4) (16,38).

Despite the shortage of physicians, they continue to dominate because they hold key positions within the health care system $(39,40)$. Physicians occupy a number of management and leadership positions at central and regional levels of the health authorities, which makes shortages of primary health care physicians worse.

\section{Figure 3 Total number of primary health care professionals in Saudi Arabia, 2010-2014 (13-17)}

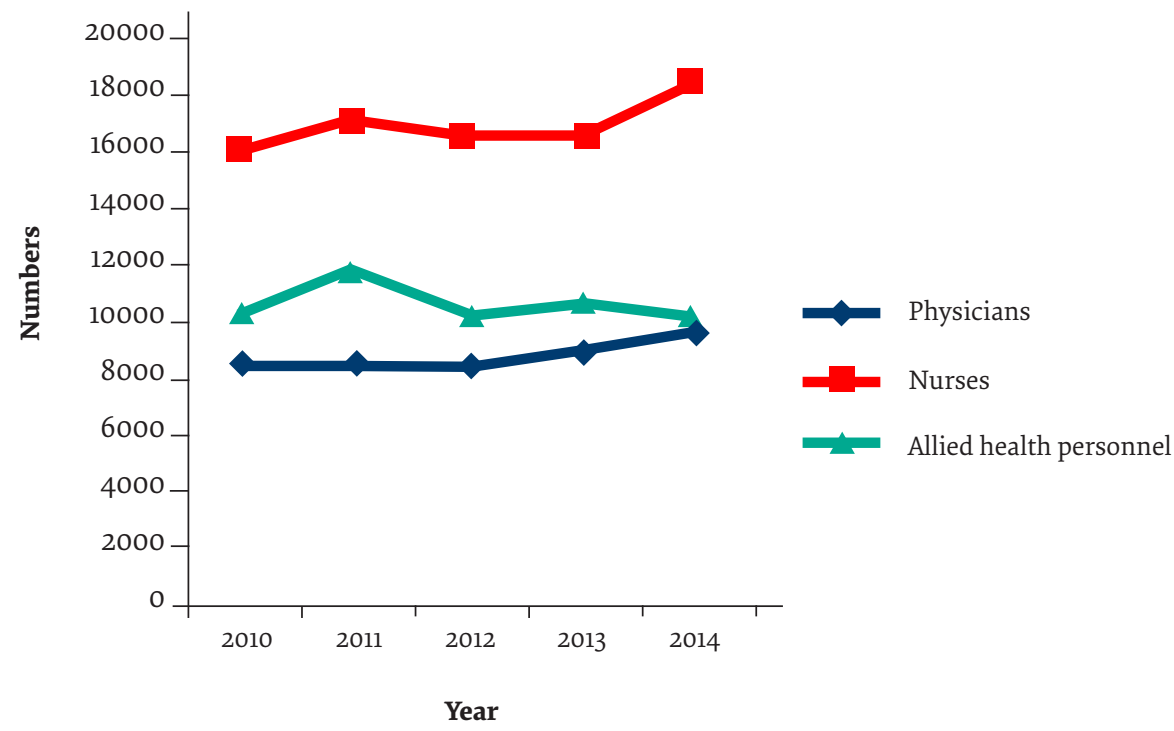


Figure 4 Practising physicians per 1000 population in various countries, $2013(16,38)$

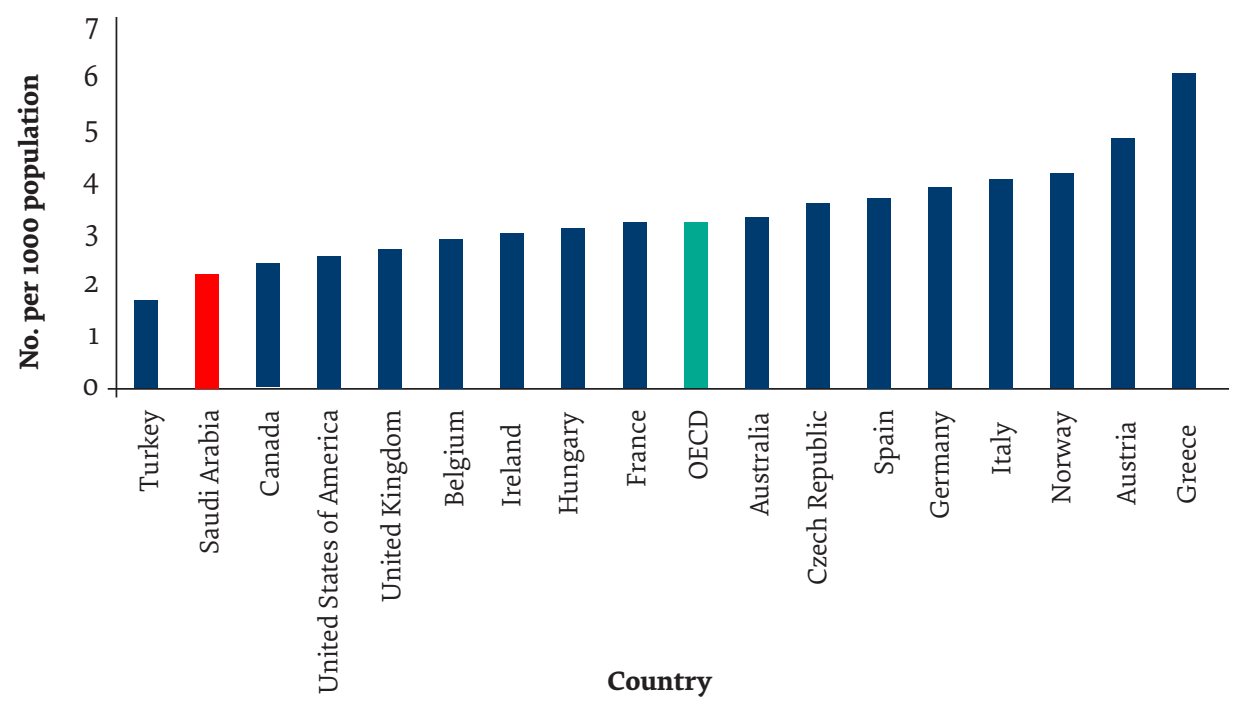

\section{Human resources' development}

The Ministry of Health has invested in training its employees and developing their skills (41). However, the large number of workers, differences in their educational and cultural background and the limited resources allocated for training have affected the number, type, and quality of available training programmes. The Ministry of Health has given local and international study scholarships to many employees. In addition, many training courses in different specialities have been launched in collaboration with the Saudi Commission for Health Specialties.

Despite these efforts, the Ministry of Health lags behind other countries in training funds for its workforce. For example, the ministries of health in both the United Kingdom and Malaysia allocate $5 \%$ of the total budget to training; in contrast, Saudi Arabia allocates only 0.4\% (6).

The Ministry of Civil Service and the Ministry of Finance strictly control recruitment activities for health care jobs, which adversely affects the available health care workforce. These ministries must approve and oversee the creation of new jobs and the recruitment of new employees or professionals to the Ministry of Health. Such policies limit the flexibility and autonomy of the Ministry of Health if it needs to update its workforce.

\section{Acceptability of and accessibility to primary health care}

Acceptability of and accessibility to the primary health care services are central to the performance and evaluation of health care systems. Acceptability is the willingness of people to seek services (42). Acceptability decreases when people perceive health services to be ineffective or when cultural and social factors (e.g. language, age, sex, ethnicity or religion) of the health care provider discourage the consumer from using services (42). Patient satisfaction studies have been used to determine the ac- ceptability of health services among populations as well as the effectiveness of the services provided (43-46). Findings from patient satisfaction surveys have been found to play a key role in reforming health care systems $(45,46)$.

A number of older studies of local health services concluded that patients in Saudi Arabia were not satisfied with primary health care services (47-51). The main reasons for dissatisfaction included the physical environment, waiting times, confidentiality measures, the location of centres, working hours, absence of speciality clinics, language and communication barriers, and the structure of the waiting area. Despite these findings, the past decade has seen a growing acceptance of primary health care services by the Saudi Arabian population. This acceptance is reflected in the total number of visits to primary health care centres during 2014, which was about 51.26 million. The average number of visits per primary health care centre was 22 473, while the average number of daily visits per centre was 90 (17). Non-availability of alternative services may lead the Saudi Arabian to accept primary care services despite their dissatisfaction. However, recent studies indicate an increased level of satisfaction with primary care services compared with previous studies (52-55).

Access to health services was been defined as "the opportunity to identify health care needs, to seek health care services, to reach, to obtain or use health care services and to actually have the need for services fulfilled" (56). The Ministry of Health identified the barriers to accessing health care services as environmental, social and economic conditions (e.g. geographical location, education level, income level and nutrition) (6). A 2014 study in Hail city, Saudi Arabia, found that the lowest level of satisfaction among primary health care users was accessing medical care and the availability of doctors (53). Another structural barrier to access to health care services is the weakness in the current referral system between the various levels of health care (57). While 
general, central and specialized public hospitals accept only referred cases, private hospitals are free to accept patients without referral. Furthermore, there is no system for sending patients back to primary health care services from general, central or specialized hospitals. More efforts are needed to reform this gap and to ensure a better continuity of primary care.

A study in Riyadh, Saudi Arabia, examined the factors influencing access to and use of primary health care centres in urban and rural areas (55). The findings highlighted important differences between urban and rural populations. For rural patients these factors included the distance to the primary health care centre, cleanliness of the centre, understanding the treatment and receiving health prevention and promotion services. Urban respondents were shown to want increased opening hours particularly in the evenings (55).

According to the World Health Organization (WHO), "The role of government with regard to sustainable health systems is to guarantee equity of access and to ensure that essential health system functions are maintained." (58). As a first level of contact between people and the health care system, primary health care services of good quality should be accessible and available to the whole population.

\section{Primary care health information system}

The Ministry of Health in Saudi Arabia developed a fouryear (2008-2011) project to improve eHealth in health care organizations and facilities $(59,60)$. However, the eHealth strategy was first implemented during 2011 in the hospitals in major cities (60). A study in 2013 aimed to identify the information needs and information-seeking behaviour of primary care physicians in Saudi Arabia (61). The findings indicated that the absence of an electronic system was a main contributor to the weaknesses of primary health care services. Primary health care physicians did not have up-to-date patient information. High-quality computing services, including electronic health records and clinical decision-making support tools, are essential to a good-quality health care service (62). Such initiatives can help deliver effective patient-centred care (63). Therefore, providing eHealth facilities within the current primary health care services is crucial to serve patients' needs and to enhance the knowledge base of physicians and other health care professionals.

\section{New primary health care reform}

To improve the quality of primary health care services, it is important to identify gaps in existing systems through review of the literature and existing health care policies and observations, and then develop and implement appropriate reforms in order to fill the gaps. This means the focus should be on primary health care structure, infrastructure, financing, management and leadership. The Ministry of Health has tried to reform the health system including primary health care services through its new reform strategy for 2010-2020 (6). The new strategy calls for the establishment of more primary health care cen- tres to meet the growing need for health services. In addition, it calls for the establishment of planned institutional work and the strengthening of monitoring of quality and performance.

Another objective of the strategy is to develop an accurate database to integrate primary health care centres. The strategy also includes the decentralization of management and empowerment of the administrative, technical and finance sectors within each level of health care. The implementation of an effective referral system from primary health care to the next level and back to primary health care is also an important objective in the proposed strategy. The development of the primary health care workforce through further education and training and new recruitment and retention strategies to address workforce shortages is also part of the reform strategy.

Although it is almost six years since the strategy was publicly announced, few changes have been introduced (personal observation). To ensure the success of this strategy, the Ministry of Health in collaboration with regional directorates must set operational plans for its implementation. In addition, a substantial portion of the Ministry of Health budget should be directed to primary health care services in order to promote population health in Saudi Arabia. The importance of such changes has increased because the Ministry of Health has recently decided to provide paid primary health care services to expatriates who work in the private sector (64), thus potentially placing an even greater burden on the primary health care system. To support this trend and promote population health, upcoming programmes and initiatives of the Saudi Vision 2030 for health should focus more on public health and primary health care services.

\section{Conclusion}

The Saudi Arabian health care system is going through a period of evolution. This has been brought about by the new vision of the Ministry of Health and the development of a national health strategy to meet the challenges. There is an urgent need to take new initiatives to improve the health care services in Saudi Arabia with a focus on reforms of primary health care services. Such reforms require the challenges in many areas of health and health to be tackled including: scope, structure, infrastructure, financing, increased demand, increased costs, workforce, inequitable access to the services, quality and safety of services, growing burden of chronic diseases, information systems, management and leadership issues, and the referral system.

Funding: None.

Competing interests: None declared. 


\section{Analyse}

\section{Système de santé public et services de soins de santé primaires en Arabie saoudite : un système en transition}

\section{Résumé}

Contexte : L'Arabie saoudite a investi massivement dans son système de soins de santé en créant des infrastructures de soins de santé en vue d'améliorer la santé de la nation. Cependant, il reste à voir si ce système est efficace et efficient pour la prestation de services de soins de santé nécessaires. Les soins de santé primaires, qui constituent la base de la couverture sanitaire universelle, devraient être évalués en termes de résultats, de défis et d'opportunités pour l'avenir afin de répondre aux besoins de la population saoudienne.

Objectifs : La présente analyse avait pour objectif d'identifier les défis à relever au sein du système de santé saoudien en mettant l'accent sur les services de soins de santé primaires et d'examiner les facteurs interdépendants afin de proposer des réformes correctives visant à renforcer et à améliorer le système de santé.

Méthodes: Un examen narratif d'études précédentes et des rapports gouvernementaux a été réalisé afin d'extraire, d'analyser, de synthétiser les résultats et d'en rendre compte.

Résultats : L'analyse a mis en évidence plusieurs domaines clés nécessitant des améliorations concernant le système de soins de santé primaires ; il s'agit notamment du champ d'application, de la structure, des infrastructures, du financement, de la demande accrue des soins, de l'augmentation des coûts et des capacités du personnel de santé. Parmi les autres défis majeurs, on mentionnera les inégalités d'accès aux services de santé, la qualité et la sécurité des services, la charge croissante des maladies chroniques, l'absence de système d'information efficace, les problèmes de gestion et d'encadrement ainsi que les lacunes du système d'orientation-recours.

Conclusion : Le système de santé de l'Arabie saoudite nécessite une réforme complète mettant l'accent sur les soins de santé primaires.

$$
\text { مشام الرعاية الصحية العامة وخدمات الرعاية الأولية في المملكة العربية السعودية: نظام يشهد تحولا }
$$

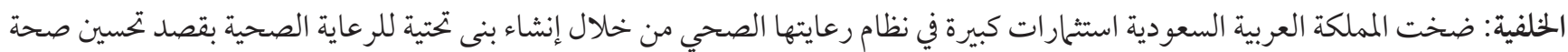

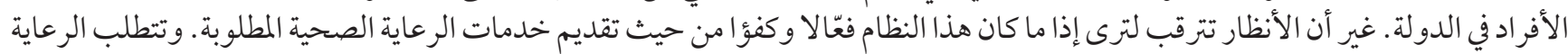

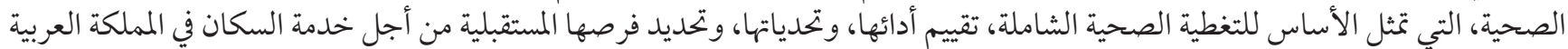
السعودية.

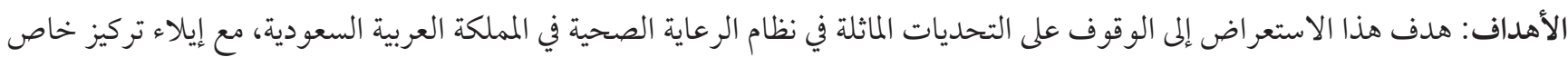

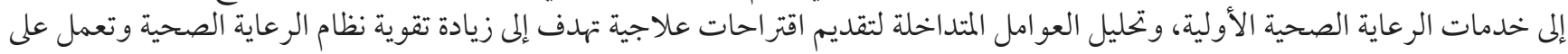
تحسينه.

$$
\text { طرق البحث: أُجري استعر اض سردي لدراسات سابقة وتقارير حكومية من أجل استخلاصها، وتحليلها، وتوليفها وإبلاغ نتائجها. }
$$

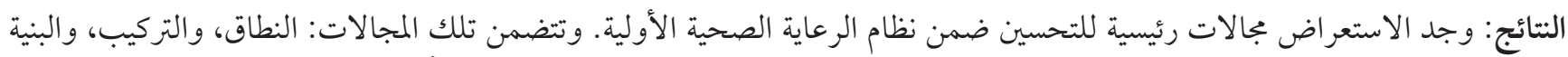

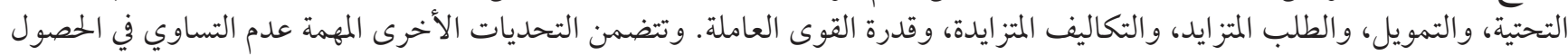

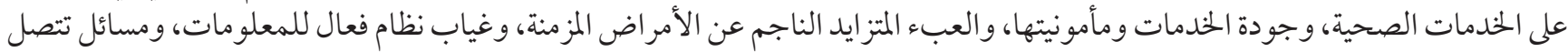
بالإدارة والقيادة، والثغرات في نظام الإحالة. الاستتاج: يجتاج نظام الرعاية الصحية في المملكة العربية السعودية إلى الإصلاح الشامل، مع التركيز بصلئل بصورة خاصة على الرعاية الصحية الأولية.

\section{References}

1. Almalki M, FitzGerald G, Clark M. Health care system in Saudi Arabia: an overview. East Mediterr Health J. 2011;17(10):784-93.

2. Yusuf N. Private and public healthcare in Saudi Arabia: future challenges. Int J Bus Econ Dev. 2014;2(1):114-8.

3. Walston S, Al-Harbi Y, Al-Omar B. The changing face of healthcare in Saudi Arabia. Ann Saudi Med. 2008;28(4):243-50.

4. Almutairi KM, Moussa M. Systematic review of quality of care in Saudi Arabia. a forecast of a high quality health care. Saudi Med J. 2014;35(8):802-9.

5. Aljuaid M, Mannan F, Chaudhry Z, Rawaf S, Majeed A. Quality of care in university hospitals in Saudi Arabia: a systematic review. BMJ Open. 2016;6:e008988. 
6. [Strategic plan of the Ministry of Health 2010-2020 - Saudi Arabia]. [In Arabic]. Riyadh: Ministry of Health; 2010 (http://www. moh.gov.sa/Portal/WhatsNew/Documents/OKIstragi26op.pdf, accessed 1 March 2017).

7. Statistical Year Book 2014. Kingdom of Saudi Arabia. Riyadh: Central Department of Statistics and Information; 2014 (https:// www.moh.gov.sa/en/Ministry/Statistics/book/Documents/Statistical-Book-for-the-Year-1435.pdf. accessed 27 August 2019)

8. Long DE. Culture and customs of Saudi Arabia. Westport, CT: Greenwood Press; 2005.

9. Bureau of Experts at the Council of Ministers. [Basic Law of Governance - Saudi Arabia]. Riyadh: The Council of Ministers; 1991. [in Arabic] (https://laws.boe.gov.sa/BoeLaws/Laws/LawDetails/16b97fcb-4833-4f66-8531-a9a70of161b6/2, accessed 24 August 2019).

10. Albougami A. Role of language and communication in providing quality healthcare by expatriate nurses in Saudi Arabia. J Health Spec. 2015;3(3):166-72.

11. Almutairi KM. Culture and language differences as a barrier to provision of quality care by the health workforce in Saudi Arabia. Saudi Med J. 2015;36(4):425-31.

12. United Nations - Population Division. World population prospects 2017 (https://esa.un.org/unpd/wpp/DataQuery/, accessed 29 April 2018).

13. Health statistics annual book 2010. Riyadh: Ministry of Health; 2010.

14. Health statistics annual book 2011. Riyadh: Ministry of Health; 2011.

15. Health statistics annual book 2012. Riyadh: Ministry of Health; 2012.

16. Health statistics annual book 2013. Riyadh: Ministry of Health; 2013.

17. Statistical year book 2014. Riyadh: Ministry of Health; 2014.

18. National accounts indicators. Riyadh: Central Department of Statistics and Information; 2016 (https://www.stats.gov.sa/sites/ default/files/national_accounts_indicators_2016.pdf, accessed 27 August 2019).

19. The World Bank. Data: Saudi Arabia (http://data.worldbank.org/country/saudi-arabia, accessed 12 January 2016).

20. [The Saudi economy in figures 1434/1435H (2013G)]. Riyadh: Ministry of Economy and Planning; 2013. [In Arabic]

21. Alrabiyah OA, Alfaleh F. [The Saudi health system reform: initiation, development and the challenges facing it]. Riyadh: Science Press and Publishing; 2010. [In Arabic]

22. The Saudi Vision 2030. Riyadh: Vision2030 Office; 2016 (https://vision2030.gov.sa/en/node, accessed 29 July 2019).

23. The executive regulation of the Saudi health system. Riyadh: Ministry of Health; 2003.

24. Al Mazrou Y, Salem A. Primary health care guide. Riyadh: Ministry of Health; 2004.

25. Alharthi F, Alenad A, Baitalmal H, Alkhurashi A. Health over a century. Riyadh: Ministry of Health and ASBAR Centre for Studies Research \& Communication; 1999.

26. Aldakhil M. Saudi food guide: palm healthy food. Riyadh: Ministry of Health; 2012.

27. Adult obesity at-a-glance. Saudi Health Information Survey for non-communicable diseases in the Kingdom of Saudi Arabia. Riyadh: Ministry of Health; 2014.

28. Diabetes at-a-glance. Saudi Health Information Survey for non-communicable diseases in Kingdom of Saudi Arabia. Riyadh: Ministry of Health; 2014.

29. Health statistics annual book, 2006. Riyadh: Ministry of Health; 2006.

30. Health statistics annual book, 2007. Riyadh: Ministry of Health; 2007.

31. Health statistics annual book, 2008. Riyadh: Ministry of Health; 2008.

32. Health statistics annual book, 2009. Riyadh: Ministry of Health; 2009.

33. World Bank. Current health expenditure per capita (current US\$). 2016 (https://data.worldbank.org/indicator/SH.XPD.CHEX. PC.CD, accessed 29 July 2019).

34. Almalki MJ. Quality of work life and turnover intention in primary healthcare organisations: a cross-sectional study of registered nurses in Saudi Arabia. Brisbane: Queensland University of Technology; 2012.

35. Whiteford L, Branch L. Primary health care in Cuba: the other revolution. Lanham: Rowman \& Littlefield Publishing Group, Inc.; 2007.

36. Global Health Workforce Alliance. Health workforce shortage focus of high level Irish conference. News release. 2012 (http:// www.who.int/workforcealliance/media/news/2012/irishforum2012/en/, accessed 12 January 2016).

37. Almalki MJ, FitzGerald G, Clark M. The relationship between quality of work life and turnover intention of primary health care nurses in Saudi Arabia. BMC Health Serv Res. 2012;12(1):314.

38. Doctors per 1000 of population. Paris: Organisation for Economic Co-operation and Development (OECD); 2014 (https://data. oecd.org/healthres/doctors.htm\#indicator-chart, accessed 2 January 2016).

39. Amir AK. The Saudi healthcare system: a view from the minaret. World Health Popul. 2012;13(3):52-64.

40. Littlewood J, Yousuf S. Primary health care in Saudi Arabia: applying global aspects of health for all, locally. J Adv Nurs. 2000;32(3):675-81. 
41. [Annual Report of the Ministry of Health]. Riyadh: Ministry of Health; 2017. [in Arabic]

42. Evans DB, Hsu J, Boerma T. Universal health coverage and universal access. Bull World Health Organ. 2013;91(8):546-546A.

43. Cabrera-Barona P, Blaschke T, Kienberger, S. Explaining accessibility and satisfaction related to healthcare: a mixed-methods approach. Soc Indic Res. 2017;133:719-39.

44. George A, Rubin G. Non-attendance in general practice: a systematic review and its implications for access to primary health care. Fam Pract. 2003;20(2):178-84.

45. Mellor D, Davison T, McCabe M, George K, Moore K, Ski C. Satisfaction with general practitioner treatment of depression among residents of aged care facilities. J Aging Health. 2006;18(3):435-57.

46. Raivio R, Jääskeläinen J, Holmberg-Marttila D, Mattila KJ. Decreasing trends in patient satisfaction, accessibility and continuity of care in Finnish primary health care-a 14-year follow-up questionnaire study. BMC Fam Pract. 2014;15(1):98.

47. Al-Faris E, Khoja T, Falouda M, Saeed A. Patient's satisfaction with accessibility and services offered in Riyadh health centers. Saudi Med J. 1996;17(1):11-7.

48. Ali MES, Mahmoud MEA. A study of patient satisfaction with primary health care services in Saudi Arabia. J Community Health. 1993;18(1):49-54.

49. Al-Sakkak MA, Al-Nowaiser NA, Al-Khashan HI, Al-Abdrabulnabi AA, Jaber RM. Patient satisfaction with primary health care services in Riyadh. Saud. Med J. 2008;29(3):432-6.

50. Mansour AA, Al-Osimy MH. A study of satisfaction among primary health care patients in Saudi Arabia. J Community Health. 1993; 18(3):163-73.

51. Al-Qatari G, Haran D. Determinants of users' satisfaction with primary health care settings and services in Saudi Arabia. Int J Qual Health Care. 1999;11(6):523-31.

52. Almoajel A, Fetohi E, Alshamrani A. Patient satisfaction with primary health care in Jubail City, Saudi Arabia. World J Med Sci. 2014;11(2):255-64.

53. Alshammari F. Patient satisfaction in primary health care centers in Hail City, Saudi Arabia. Am J Appl Sci. 2014;11(8):1234-40.

54. Mohamed EY, Sami W, Alotaibi A, Alfarag A, Almutairi A, Alanzi F. Patients' satisfaction with primary health care centers' services, Majmaah, Kingdom of Saudi Arabia. Int J Health Sci. 2015;9(2):163-70.

55. Alfaqeeh G, Cook E J, Randhawa G, Ali N. Access and utilisation of primary health care services comparing urban and rural areas of Riyadh Province, Kingdom of Saudi Arabia. BMC Health Serv Res. 2017;17:106.

56. Levesque J-F, Harris MF, Russell G. Patient-centred access to health care: conceptualising access at the interface of health systems and populations. Int J Equity Health. 2013;12(1):18.

57. Senitan M, Alhaiti A, Gillespie J. "Ehalati": evaluation of the referral system in primary health care centres in Saudi Arabia. Int J Integr Care. 2018;18(s2):326.

58. Health for All in the 21st Century. Geneva: World Health Organization; 1997 (http://applications.emro.who.int/docs/em_rc44_10_ annex_en.pdf, accessed 29 July 2019).

59. Qurban H, Austria RD. Public perception on e-health services: implications of preliminary findings of KFMMC for military hospitals in KSA. Paper presented at the European and Mediterranean Conference on Information Systems, Dubai, 25-26 May, 2008.

60. [National e-health strategy]. Riyadh: Ministry of Health; 2013. [In Arabic]

61. Alghanim SA. Information needs and seeking behavior among primary care physicians in Saudi Arabia: implications for policy and practice. Sci Res Essays. 2011;6(8):1849-55.

62. Hasanain R, Vallmuur K, Clark M. Progress and challenges in the implementation of electronic medical records in Saudi Arabia: a system review. Health Informatics - an International Journal. 2014;3(2):3214.

63. Liyanage H, Correa A, Liaw S, Kuziemsky C, Terry A, de Lusignan S. Does informatics enable or inhibit the delivery of patient-centred, coordinated, and quality-assured care: a Delphi study. Yearb Med Inform. 2015;10(1):22-9.

64. [Organizational guide for the paid health services program]. Riyadh: Ministry of Health; 2018. [In Arabic]. 